\title{
EVALUATING THE RELIABILITY OF AMS DATES ON FOOD RESIDUE ON POTTERY FROM THE LATE PREHISTORIC CENTRAL PLAINS OF NORTH AMERICA
}

\author{
Donna C Roper \\ Department of Sociology/Anthropology/Social Work, Kansas State University, 204 Waters Hall, Manhattan, Kansas 66506, \\ USA. Email: droper@ksu.edu.
}

\begin{abstract}
Age offsets of accelerator mass spectrometry (AMS) assays on food residue taken from pottery vessels are well-documented in Europe and Asia in cultural contexts were freshwater aquatic products are attested, but are less well studied in North America. The present study examines a series of residue dates from the late prehistoric Central Plains of North America, comparing them with context dates run on annual plant remains. At least 13 of 23 assays are either incongruent with ages on annual plant remains, inconsistent among themselves within a site, or not credible for their cultural context. The conclusion is that food residue from ceramics does not produce consistently accurate dates. Some possible factors that may serve to introduce old carbon to residue samples are discussed. It also is noted that one's conclusions about the reliability of residue may be conditioned by the precision of the age determinations and by the goals of a specific chronology-building effort.
\end{abstract}

\section{INTRODUCTION}

Some accelerator mass spectrometry (AMS) assays run on ceramic residue (foodcrusts) exhibit significant age offsets when evaluated relative to context dates on other short-lived materials, and this is now well-documented in northern Europe and parts of Asia (Fischer and Heinemeier 2003; Craig et al. 2007; Boudin et al. 2009, 2010; Louwe Kooijmans 2010; Philippsen et al. 2010; Miyata et al. 2011; Crombé et al. 2012; other studies published in languages other than English are cited in some of these references). The offsets are attributed to a freshwater effect that introduces old carbon into food via fish processed in the vessels (Fischer and Heinemeier 2003). Age offsets are most notable in Mesolithic contexts, where aquatic products (fish and crustaceans, herein glossed as fish) are attested for the specific foodcrust samples or at least are likely in the sampled cultural context. In contrast, age assays on residue from Neolithic and Bronze Age context, where fish is not attested, usually are consistent with context dates (Timofeev et al. 1995; Hallgren and Possnert 1997; Kriiska et al. 2005; Shishlina et al. 2007).

This phenomenon is much less well studied in North America, perhaps because the number of residue dates employed in a study has, until recently, usually been small. In these instances, identified age offsets may be disregarded (Redmond 2006a:37; Ahler et al. 2007:87), or comparisons cannot be made because suitable context dates either are lacking (Redmond 2006b) or were assayed on wood charcoal (Ritterbush 2002:261). Recently, however, Hohman-Caine and Syms (2012) recognized a reservoir effect in a study designed to determine the age of Brainerd ware pottery in Minnesota, and tempered their conclusions accordingly. Earlier, Schulenberg (2002) and Hart and Brumbach $(2003,2005)$ used residue dates to argue that the manufacture of Owasco pottery in New York began earlier than previously thought (Schulenberg 2002) and that certain prehistoric cultural complexes of New York state also were somewhat older than previously supposed (Hart and Brumbach 2003, 2005; see also Hart 2011). Hart and Lovis (2007a) also have published a large study of the reliability of accumulated residue dates from multiple sites in New York State and the Great Lakes region, concluding that dates on residue are consistent with those on other materials. They also (Hart and Lovis 2007b) have argued that the Fischer and Heinemeier (2003) results from one of the European sites were affected by a single outlier.

This paper contributes to the discussion of the reliability of AMS age determinations on food residue on ceramics by examining a series of high-precision AMS dates from the Central Plains tradition of the North American Central Plains and evaluating both their concordance within specific contexts 
and their fit within the overall regional chronology developed on short-lived materials other than residue, principally annual plant remains. The conclusion will be that while some dates on residue are consistent, others are not, and thus that residue does not yield consistently accurate results. While no conclusions as to why this happens are offered here, a discussion will highlight some factors that may contribute to these results. It also is suggested that the nature of the site components from which samples are selected and the goals, and hence needs, of a chronology-building effort are a factor in acceptance or non-acceptance of the reliability of dating residue.

\section{THE CASE FROM THE NORTH AMERICAN CENTRAL PLAINS}

The Central Plains tradition encompasses sites in a large area of Kansas and Nebraska, as well as portions of northwest Missouri and southwest Iowa (Roper 2006). The study presented here is limited to the southern part of this cultural subarea, and specifically to sites in the Kansas River basin and an adjacent segment of the Missouri River drainage in northern Kansas, southern Nebraska, and extreme northwest Missouri (Figure 1). The bedrock formations throughout the area are variably composed, but include shale, limestone, and carbonate-cemented conglomerates. The people of the Central Plains tradition lived in small farmsteads loosely dispersed along the valleys of the major trunk streams of the Central Plains or in the valleys of larger tributaries of those streams. Farmsteads were centered on small (about $8 \times 8 \mathrm{~m}$ ) wattle-and-daub structures whose use-lives probably were on the order of a decade or so. Subsistence was generalized, with an agricultural component in which corn was ubiquitous and other cultigens are attested, as is the use of wild and weedy plant foods and the procurement of a highly diverse fauna. Importantly, remains of fish and freshwater mussels may be abundant in assemblages discovered using comprehensive recovery procedures. Artifact assemblages include a diverse set of pottery vessel forms, including cooking pots exhibiting burnt-on food residue. Much of the pottery is mineral-tempered, but shell-tempered material appears, particularly in the Missouri River Valley and its immediate drainage, and in the eastern part of the study area beyond the Missouri River (Roper 2011a). Petrographic analysis on pottery suggests that alluvial formations, potentially including wetlands with organic-rich bottom sediments, may have been an important clay source.

The existing Central Plains tradition chronology largely is a radiocarbon chronology. A total of 431 age determinations from 150 sites have been assayed, with 274 of them from 97 contexts (usually a single wattle-and-daub lodge) in the area encompassed by this analysis. These age determinations have accumulated over almost exactly half a century. About two-thirds of them (179 of the 274, or $65.3 \%$ ) were run on wood charcoal and have standard deviations as large as $440 \mathrm{yr}$. One is on shell and is not credible. At present, however, 69 dates (25.2\%) have been run on either annual plants, including charred grass, or such other short-lived materials as small twigs. A total of 23 dates (8.4\%) have been run on residue. The final 2 dates are on bone. The large majority of the dates on annuals or residue were assayed in the last decade or so and especially the last few years in an effort to either evaluate the appearance of specific cultigens on the Central Plains (Adair 2003) or upgrade the existing chronology by basing it on short-lived materials (Roper and Adair 2011, 2012; Roper 2012a). Most residue dates were obtained when curated collections were found to have either no annual plant remains or insufficient amounts of them to permit obtaining multiple age determinations. Several were obtained in the last $2 \mathrm{yr}$ in the only instance reported here of deliberately pairing residue samples with context dates on annual plant remains (corn, in this case) from a newly excavated site to evaluate the reliability of the residue dates (while also evaluating the time of site occupation). In a few other cases, although the pairing was not deliberate, both annual plants and residue have been dated. 


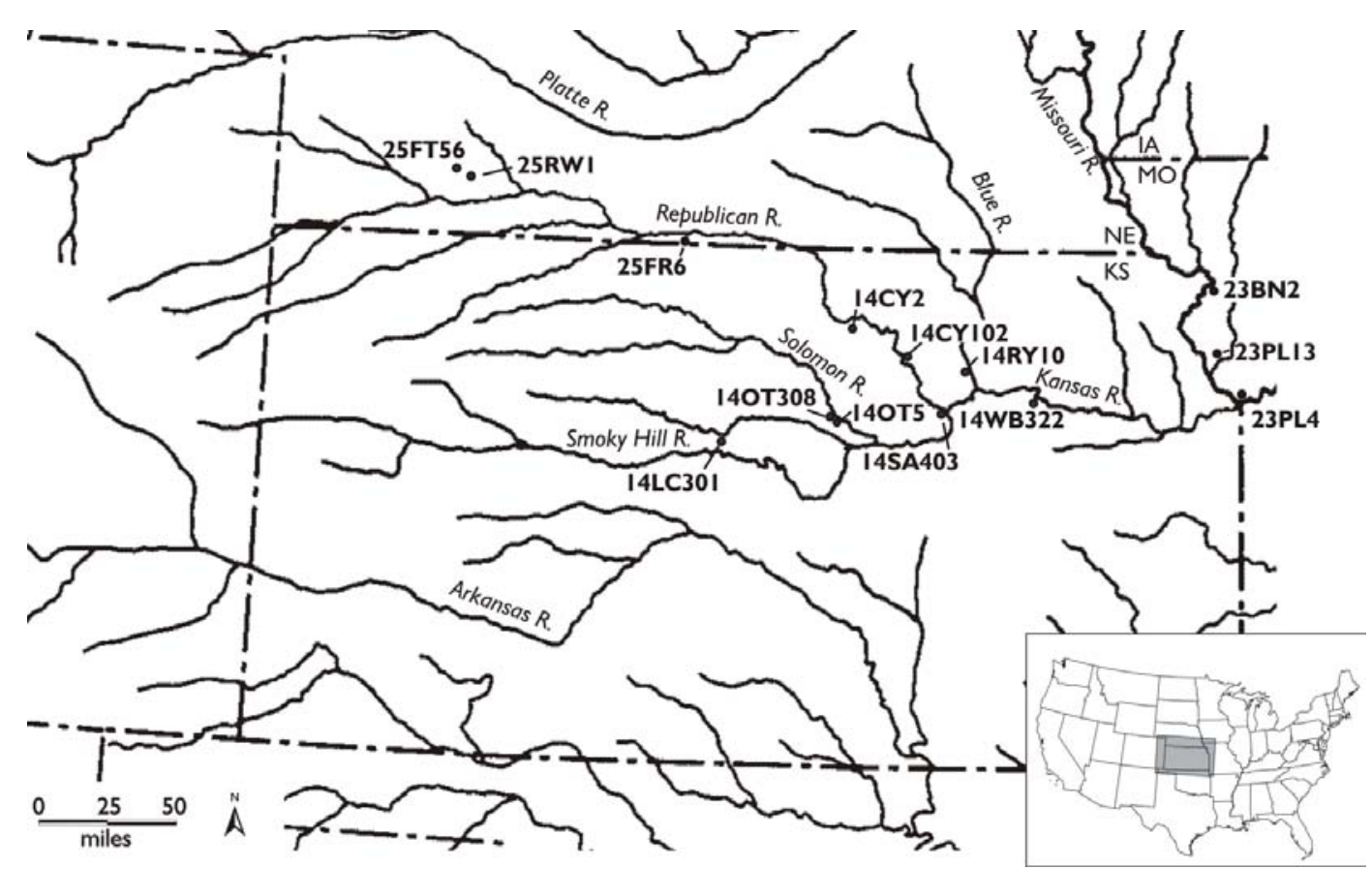

Figure 1 The general locations of sites discussed in this article. The inset shows the region within the United States.

Synthetic studies normally state the time of the Central Plains tradition at around AD 1000-1500, $1000-1400$, or 900-1400. These estimates are based largely on charcoal dates and have not been seriously updated using age determinations on short-lived materials. The recent accumulation of dates on short-lived materials has been directed toward both reassessing the time interval involved and seeking to make distinctions within it. To this end, a chronometric hygiene protocol appropriate for this data set has been developed and applied to the dates. It removes dates run at the Gakushuin laboratory, due to an earlier demonstration of the unreliability of these dates for this cultural tradition (Blakeslee 1994), and the single date on shell, and it initially excludes dates with standard deviations of $100 \mathrm{yr}$ or more. The final analysis actually uses very few dates with standard deviations of $60 \mathrm{yr}$ or more. The protocol then sorts the remaining dates by varying levels of confidence depending on the material. Dates are compared within each context individually and their consistency is evaluated. Dates that survive this may be pooled for each individual context and calibrated to obtain an estimate of the time of site occupation. The results, presented in preliminary form at a regional conference (Roper 2012b) and included in Figure 2, narrow the time of the Central Plains tradition in the study area to around cal AD 1150-1400 or possibly even little beyond cal AD 1150-1350, and show that the Central Plains tradition lifeway was practiced over a particularly extensive area in the period cal AD 1250-1350 (Figure 2). Importantly, the calibrated dates appear to indicate some differential timing of the appearance of this lifeway in various localities with the study area, due at least in part to an expansion within the study area, and possibly to different times of abandonment of localities. It is this chronology against which we assess the reliability of residue dates. 


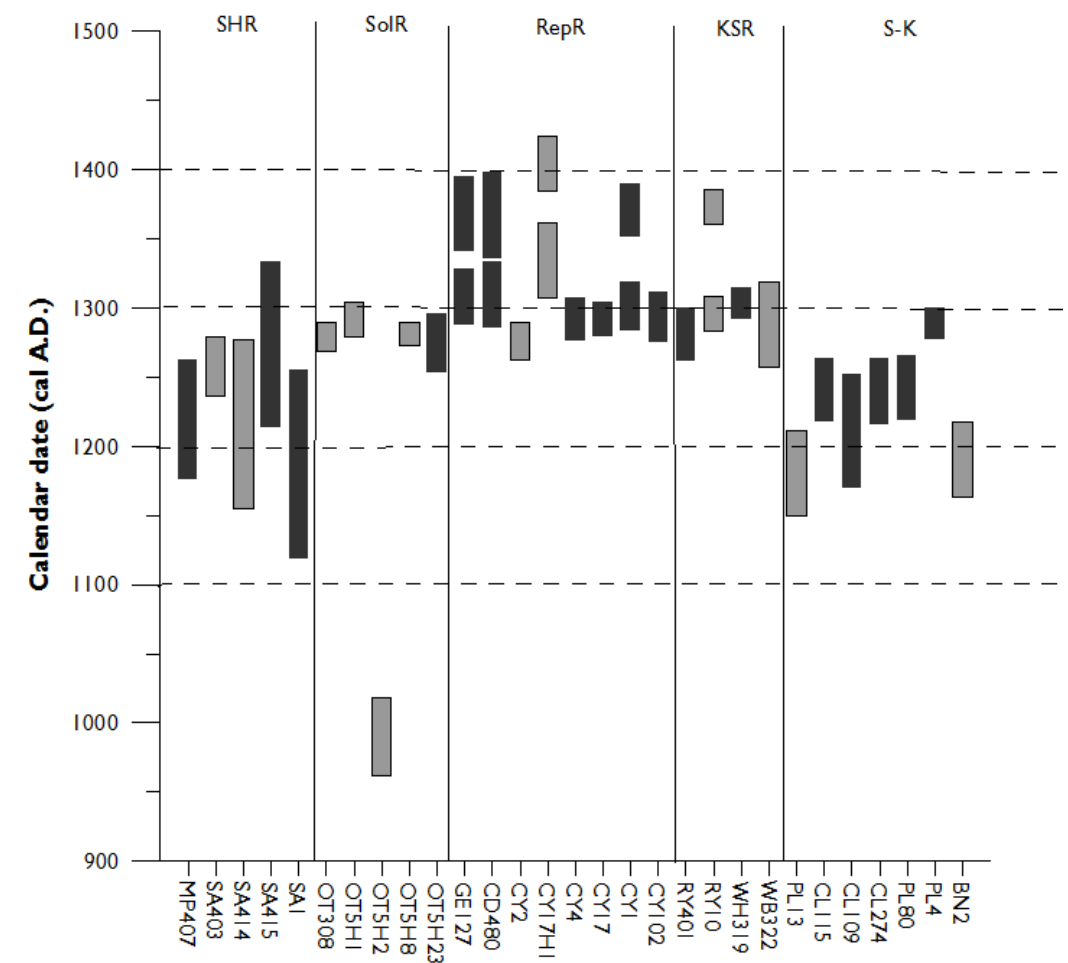

Figure 2 Date estimates derived from concordant and pooled age estimates for Smoky Hill phase and Steed-Kisker sites, by locality. Bars represent $2 \sigma$ calibrated date ranges. Solid dark bars represent dates with a high level of confidence; solid gray bars are dates with somewhat reduced confidence, sometimes because a date on residue enters into the calculation. Abbreviations: SHR = Smoky Hill River; SolR = Solomon River proper; RepR = Republican River (lower reaches); KSR = Kansas River; S-K = Steed-Kisker phase sites).

\section{ANALYSIS AND RESULTS}

Taking first an exploratory data analysis approach, box-and-whisker plots (Figure 3a) of ${ }^{14} \mathrm{C}$ ages afford a first look at the distribution of age determinations on residue and a comparison with ages on other materials. This plot is based on 270 of the 274 age determinations from the study area (the exceptions are an obviously erroneous date of around $14,100 \pm 100{ }^{14} \mathrm{C}$ yr BP on charcoal, a date of $3395 \pm 295{ }^{14} \mathrm{C}$ yr BP on shell, and the 2 age determinations on bone). Expectably, the charcoal dates span the widest age range, and the median of $810{ }^{14} \mathrm{C}$ yr BP is the oldest of the 3 medians. At $790{ }^{14} \mathrm{C}$ yr BP, however, the median residue age is only slightly younger, and the early part of the age range is elongated. In contrast, the median age on annuals is $699{ }^{14} \mathrm{C}$ yr BP, and the fourth quartile range is short, with a maximum age barely older than the third quartile value of the residue ages. This is the first indication that the ages on residue might be portraying the Central Plains tradition chronology somewhat differently than are the ages on annuals. A histogram of ages on residue superimposed on a histogram of ages on annuals, each plotted using 50-yr bins (Figure 3b), shows the rather different distribution of ages on the 2 sample materials.

Residue dates and context dates (Table 1) may also be specifically compared for individual contexts. With 1 exception, each context is neither more nor less than an individual short-lived lodge; the exception is a very short-term occupation campsite. This analysis is based on 1 premise and 5 expec- 

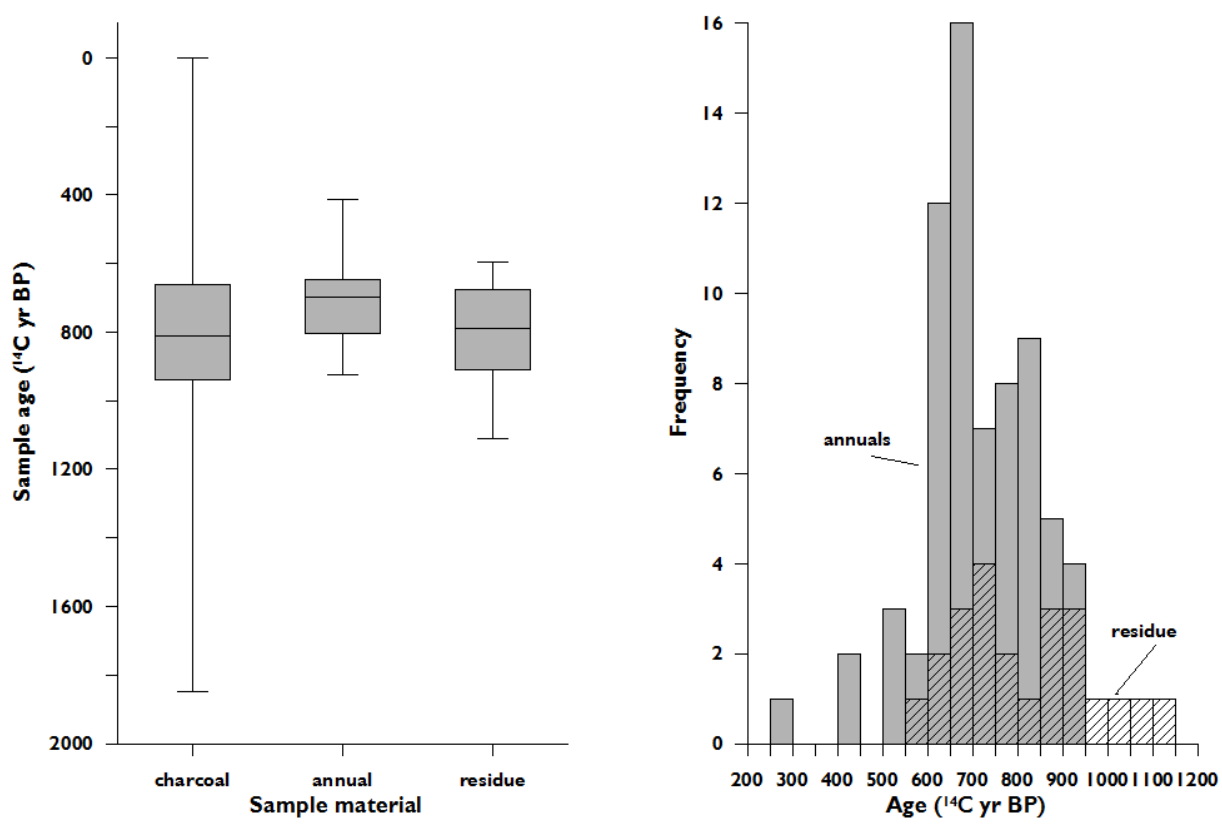

Figure 3 a) Box-and-whisker plot of ages grouped by material (charcoal $n=178$; annuals $n=68$; residue $n=23)$ and b) a histogram of the annuals $(n=68)$ and residue $(n=23)$ dates for the 274 age determinations from 97 sites in the area encompassed by this paper.

tations that follow from that premise. The premise is that the life of an individual lodge, the context unit for most date series examined here, almost certainly was less than 1-standard deviation of even the highest-precision dates. Therefore, we expect accurate estimators of an occupation's age to meet the following conditions:

- All dates on materials in valid association with the occupation should be statistically the same. More specifically:

- Within each individual context, ages on residue should be statistically the same as ages on annuals.

- Ages on residue should be concordant with one another within their context.

- Ages on wood charcoal, unless known to be on outer rings or short-lived materials such as twigs or small branches, may or may not be concordant with residue. Discrepancies among these ages may vary in magnitude, leaving the charcoal dates inadequate as context dates against which to evaluate the residue ages.

- When ages on residue are the only ages for a context, they cannot be closely evaluated for accuracy, but they should fall within the general temporal parameters for the taxon, especially if the parameters were established by dating annuals.

The analysis of each site individually and discussion of those sites individually follows. It should be noted that the regional chronology shown in Figure 2 does retain several residue dates. In all cases, these dates are statistically the same as context dates on annuals or short-lived charcoal. The results discussed below were obtained during assessment of the individual age determinations that went into the chronology and in essence are 1 result of the analysis. 
Table 1 Dates used in this analysis.

\begin{tabular}{|c|c|c|c|c|}
\hline Site & Lab nr & Age & Material & Reference \\
\hline \multicolumn{5}{|c|}{ Sites with dates on residue and on annuals } \\
\hline \multirow[t]{3}{*}{ 23PL4 } & ISGS-A1725 & $790 \pm 20$ & residue & Roper and Adair 2012 \\
\hline & ISGS-A1731 & $685 \pm 20$ & bean & Roper and Adair 2012 \\
\hline & ISGS-A1732 & $685 \pm 20$ & bean & Roper and Adair 2012 \\
\hline \multirow[t]{3}{*}{ 14WB322 } & ISGS-A1724 & $1110 \pm 25$ & residue & Roper and Adair 2012 \\
\hline & TX-? & $810 \pm 70$ & charcoal & Roper 2005 \\
\hline & AA-96465 & $698 \pm 35$ & hackberry seed & Roper 2012a \\
\hline \multirow[t]{2}{*}{ 14RY10 } & ISGS-A1556 & $665 \pm 15$ & residue & Roper and Adair 2011 \\
\hline & AA-85341 & $647 \pm 33$ & maize & Roper and Adair 2011 \\
\hline \multirow[t]{4}{*}{ 14CY102 } & ISGS-A1548 & $705 \pm 15$ & residue & Roper and Adair 2011 \\
\hline & ISGS-A1549 & $705 \pm 15$ & residue & Roper and Adair 2011 \\
\hline & AA-85339 & $692 \pm 35$ & maize & Roper and Adair 2011 \\
\hline & AA-85340 & $663 \pm 35$ & maize & Roper and Adair 2011 \\
\hline \multirow[t]{6}{*}{ 25FT56 } & PRI-140-219-2 & $660 \pm 60$ & residue & Roper 2012a \\
\hline & PRI-140-221 & $610 \pm 15$ & residue & Roper 2012a \\
\hline & PRI-140-222-2 & $610 \pm 20$ & residue & Roper 2012a \\
\hline & PRI-140-218 & $605 \pm 20$ & charcoal & Roper 2012a \\
\hline & PRI-140-221-2 & $585 \pm 20$ & maize & Roper 2012a \\
\hline & PRI-140-222-1 & $585 \pm 20$ & maize & Roper 2012a \\
\hline \multicolumn{5}{|c|}{ Sites with dates on residue and on charcoal } \\
\hline \multirow[t]{2}{*}{ 14SA403 } & ISGS-A1558 & $755 \pm 15$ & resid & Roper and Adair 2011 \\
\hline & Beta & $860 \pm 60$ & char & Roper and Reed 2003 \\
\hline \multirow[t]{2}{*}{ 14ОТ308 } & ISGS-A1553 & $715 \pm 15$ & residue & Roper and Adair 2011 \\
\hline & Beta & $730 \pm 60$ & charcoal & Roper and Reed 2003 \\
\hline \multirow[t]{3}{*}{ 14LC301 } & ISGS-A1551 & $990 \pm 15$ & residue & Roper and Adair 2011 \\
\hline & ISGS-A1554 & $935 \pm 15$ & residue & Roper and Adair 2011 \\
\hline & $\mathrm{I}-509$ & $963 \pm 100$ & charcoal & Witty 1962 \\
\hline \multicolumn{5}{|c|}{ Sites with residue dates only } \\
\hline \multirow[t]{2}{*}{ 23PL13 } & ISGS-A1728 & $900 \pm 20$ & residue & Roper and Adair 2012 \\
\hline & ISGS-A1729 & $885 \pm 20$ & residue & Roper and Adair 2012 \\
\hline \multirow[t]{3}{*}{ 23BN2 } & ISGS-A1460 & $905 \pm 15$ & residue & Roper and Adair 2011 \\
\hline & ISGS-A1726 & $860 \pm 20$ & residue & Roper and Adair 2012 \\
\hline & ISGS-A1727 & $850 \pm 20$ & residue & Roper and Adair 2012 \\
\hline 14OT5-H1 & ISGS-A1552 & $675 \pm 15$ & residue & Roper and Adair 2011 \\
\hline 14OT5-H2 & ISGS-A1547 & $1070 \pm 15$ & residue & Roper and Adair 2011 \\
\hline $14 \mathrm{CY} 2$ & ISGS-A1550 & $725 \pm 20$ & residue & Roper and Adair 2011 \\
\hline \multirow{2}{*}{ 25FR6 } & ISGS-A1790 & $1015 \pm 20$ & residue & Roper and Adair 2012 \\
\hline & ISGS-A1791 & $910 \pm 15$ & residue & Roper and Adair 2012 \\
\hline 25RW1 & PRI-140-1-1 & $595 \pm 20$ & residue & Roper 2012a \\
\hline
\end{tabular}

\section{Sites with Dates on Residue and on Annuals}

23PL4. Two age determinations from 23PL4 were on beans (Phaseolus vulgaris); the other was on residue from a shell-tempered sherd. The 3 ages are significantly different $(T=18.735, d f=2, p=$ 0.0001). The 2 ages on beans are identical to one another, but the residue date is $105{ }^{14} \mathrm{C}$ yr older and is the outlier.

14WB322. The 3 age determinations from 14WB322 include 1 each on charcoal, residue, and an annual plant (charred hackberry seeds). The 3 dates are statistically different from one another $(T=$ 
96.620, $d f=2, p<0.001)$. The residue date, which is from the interior surface of a shell-tempered sherd, is the outlier. It is $300 \mathrm{yr}$ older than the charcoal date and $412 \mathrm{yr}$ older than the date on seeds. Fish and mussel use is abundantly attested at this site; in fact, the site is identified as a fish and mussel processing camp. The ceramic vessel, however, likely was not a cooking pot (Roper 2005).

14RY10. Two dates for $14 \mathrm{RY} 10$ are 1 each on corn and residue (temper not recorded). The residue date is $18{ }^{14} \mathrm{C}$ yr older than the corn date and the 2 dates are statistically the same $(T=0.247, d f=1$, $p=0.619$ ).

14CY102. Five age determinations from 14CY102 include 1 on charcoal, 2 on corn, and 2 on residue taken from mineral-tempered sherds. The 5 ages collectively are statistically different from one another ( $T=7.954, d f=4, p=0.027$ ). The age on charcoal is the outlier here, and it is notably younger than the other ages. The other 4 ages are statistically the same $(T=1.386, d f=3, p=0.709)$. The 2 residue dates are identical to one another and are 18 and $42{ }^{14} \mathrm{C}$ yr older than the 2 ages on corn.

25FT56. Having become aware of a potential issue with dating residue by the time site 25FT56 was investigated (in mid-2011), a deliberate comparison of residue and context dates could be made. A small rounded piece of charcoal was misidentified as corn when selecting samples under poor lighting conditions in the field, but otherwise, the comparison involved 2 corn kernels and 3 samples of residue from the same excavated features. All residue was taken from mineral-tempered sherds. Fish and mussels are not attested in the faunal remains from this site. The 6 ages collectively are the same statistically ( $T=2.844, d f=5, p=0.724)$. However, it is notable that 2 of the 3 residue dates are $25{ }^{14} \mathrm{C}$ yr older than the dates on corn and the third is $75 \mathrm{yr}$ older than the corn dates. This oldest residue age was assayed on a small sample (8 $\mathrm{mg})$ and has a 60-yr standard deviation.

\section{Sites with Dates on Residue and on Charcoal}

14SA403. Three charcoal assays and 1 on residue have been run for 14SA403. Two charcoal dates are far too old to be credible. Testing the other charcoal date and the residue date, which is from a mineral-tempered vessel, indicates that the 2 dates are not quite statistically different $(T=2.882$, $d f=1, p=0.090$ ). The charcoal sample was not from an outermost ring of the tree limb, leaving the comparison of limited value. The residue age is at least compatible with ages on annuals for sites in this locality.

14OT308. Two age determinations for 14OT308 include 1 each on charcoal and residue from a mineral-tempered vessel. The 2 ages are statistically the same $(T=0.059, d f=1, p=0.808)$. This charcoal sample also was not an outermost ring of the tree limb involved, and thus must have some age offset. Again, however, the residue date is at least credible for the cultural context in its locality.

14LC301. Site 14LC301 is dated by 1 assay on charcoal and 2 on residue from mineral-tempered vessels. The age on charcoal has a 100-yr standard deviation and is disregarded for further analysis. The ages of the 2 residue dates also are statistically different than one another $(T=6.722, d f=1, p=$ 0.010). Each of them also is roughly at least 150 to $200{ }^{14} \mathrm{C}$ yr older than would seem credible for this cultural context.

\section{Sites with Residue Dates Only}

23PL13. Two age determinations on residue from 23PL13 are statistically the same $(T=0.28, d f=$ $1, p=0.597)$. These are among the earliest of the age determinations on short-lived materials from this locality. Pooled and calibrated, they yield a date that is reasonable (Figure 3), but also is the earliest pooled age for any component for this locality dated with short-lived materials. 
23BN2. Three age determinations from 23BN2 all were assayed on residue, 1 from a shell-tempered sherd, 1 from a mineral-tempered sherd, and 1 from a sherd for which temper is not recorded. The 3 ages are not statistically the same $(T=6.007, d f=2, p=0.0496)$. Sample ISGS-A1460 (from the sherd for which temper is not recorded) is 45 and 55 yr older than are the other 2 samples.

14OT5-H1. The only sample from House 1 at 14OT5 is on residue from a mineral-tempered vessel. Although there is nothing to compare it with, it is a credible date for its cultural context.

14OT5- $\mathrm{H} 2$. House 2 at $14 \mathrm{OT} 5$ also has only 1 age determination on residue from a mineral-tempered vessel. This age, although without a comparison from the same context, is on the order of 2 to, more likely, 3 centuries too old for its cultural context.

14CY2. The single age determination for 14CY2-H2 is on residue from a mineral-tempered vessel. Its age is reasonably credible for its cultural context as a whole, although it is an early date for its locality (Figure 2).

25FR6. Two age determinations from 25FR6 are each on residue from mineral-tempered vessels. The 2 ages are statistically different from one another $(T=17.64, d f=1, p<0.001)$. Each also is 2 , 3 , or even possibly as many as 4 centuries too old for this cultural context.

25RW1. The single age determination for 25RW1 is on residue from a mineral-tempered vessel. This site is $<10$ miles from 25FT56 and is culturally equivalent. The age is very similar to the ages on both the corn and the residue samples from 25FT56 and is credible for its cultural context. Fish is not attested in the locality of these 2 sites and mussel use seems quite limited, even though preservation in this locality is excellent and even when comprehensive recovery techniques have been used.

\section{DISCUSSION}

The analysis indicates that 7 of the 23 age determinations on residue, from 5 contexts (23PL4, 14WB322, 14LC301, 14OT5-H1, and 25FR6), are incongruent either with context dates or with the currently accepted date span for the cultural context (or both). Observed age offsets are usually around 1 to 4 centuries, with a modal value of 2 to 3 centuries. Another 6 dates from 3 contexts (23PL13, 23BN2, and 14CY2) are credible for their cultural context, but fall toward the early end of the time range for that context, or even provide the earliest dates for their locality. In 1 instance (23BN2), multiple residue dates are not congruent with one another. In only 10 of the 23 instances, from 7 sites (14RY10, 14CY102, 25FT56, 14SA403, 14OT308, 14OT5-H1, and 25RW1), therefore, are the residue dates both congruent, when direct comparisons with context dates on annuals are possible, and fully credible for their cultural context and locality. Even then, 2 of them have only single charcoal dates for comparison, and neither charcoal date is a minimum age. Two other residue ages, although credible, have no possible comparison at present.

Overall, then, the stated expectations for reliable residue dates are not consistently met by this set of dates. Multiple dates within a series for a given occupation are not always congruent with one another. Ages on residue are not always statistically the same as ages on annuals and, when incongruities arise, it is residue dates, not dates on annuals, that are incongruent. Ages on residue are not always concordant with one another within a specific context, and ages on residue, whether or not concordant with one another, are not always credible for their cultural context, i.e. the general temporal parameters for the taxon and sometimes not for the locality within a taxon. Although some specific residue dates are not suspect, significant questions can be raised about more than half of the dates, leading to the conclusion that the consistent accuracy of age determinations on residue in this region is suspect. 
Determining why some residue dates are discrepant has proved difficult. As noted earlier, the people of the Central Plains tradition did incorporate aquatic products into their diets, so the freshwater reservoir effect is a definite possibility, and seems likely in light of findings from elsewhere. It may not be the only way age offsets occur, however. The vessel with one of the largest age offsets, that from 14WB322, is not a cooking pot, and analysis of absorbed residues using Fourier transform infrared spectroscopy (FTIR) suggests it held an oil, but not a fish oil. On the other hand, the vessel was found in a hearth that had been used for steaming a large mass of fish and freshwater mussels, and it seems possible that at least some of the surface residue and the dirt that is intermixed with it could have been impregnated with oils from those products. The only other vessels for which we currently have FTIR data are the sherds from 25FT56 and 25RW1 from which residue was scraped. Absorbed residues from these vessels do not indicate fish (Cummings et al. 2011), nor is fish attested in the faunal remains from either site. Here, the residue dates were expected to not be discrepant and, indeed, their ages showed small, and statistically not significant, offsets from the context dates. All other age determinations were run on materials from curated collections, most of which resulted from work done in the mid-20th century. For none of these were comprehensive recovery techniques used, and in some cases no faunal remains were retained. The presence of fish is definitely plausible, although it cannot be evaluated for each case specifically using associated faunal assemblages. Further residue testing is needed for these instances.

Recognizing, therefore, that not all age offsets may be due to a reservoir effect, additional factors that may introduce old carbon should be considered. One observation for this date series is that a number of the samples yielding incongruent ages were residue scraped from shell-tempered pottery. It is not likely that shell particles were incorporated into the residue when it was extracted, and, in any event, laboratory pretreatment should have removed them as contaminants. However, in many cases, the shell has been leached, leaving one to wonder where the leachate must have gone, and if some of it might have been absorbed into and affected the residue. On the other hand, some of the dates on residue from shell-tempered sherds are congruent with context dates, and some of the incongruent dates are on residue from mineral-tempered sherds. Another possibility, not yet tested, might be that nixtamalizing corn could introduce old carbon, although it is not known if people on the Central Plains were nixtamalizing corn in the late prehistoric period. Further, cooking in ceramic vessels often involves boiling in water. It seems possible that hardwater itself may introduce old carbon to food. Yet another possible source of old carbon might be organic matter that remains within the vessel fabric and is continually being brought to the surface and removed during vessel use for cooking (Beck 2010:49-54).

Several recurring circumstances under which residue dates are congruent with dates on short-lived context materials can also be identified. The 25FT56 case, where residue dates are congruent with dates on corn, is one where fish is not attested in a site excavated using comprehensive recovery techniques. This at least does not contradict expectations, although it is a weak form of evidence.

One circumstance rarely examined is if and how pottery vessels yielding residue may have differentially functioned in a particular cultural milieu. In the Central Plains tradition case, vessel form diversity is evident, and several forms of cooking pots can be defined (Roper 2011b). At least some historic tribes are known to have used separate pots to prepare meat and fish (e.g. Swanton 1942: 174), so if fish products do indeed add old carbon to residue and produce incongruent dates, then age determinations on residue from pots used for fish and those on residue from pots used for meat (or other foods, such as vegetables) should be discrepant relative to one another within a given context, even though their uses were contemporaneous with one another. Preliminary examination of absorbed residues from several Central Plains tradition cooking pots suggests that some were and 
some were not used for preparing fish dishes (Cummings and Roper 2010). This probably will not be the case in all cultural contexts where fish is part of the diet, and it will need to be examined on a case-by-case basis. It is not causal, of course, but if vessel form and vessel function were found to be correlated in a particular cultural setting, vessel form could be a useful predictor of which residue deposits are and are not likely to yield accurate dates, although it would still be necessary to ensure that no other sources of old carbon were affecting residue dates.

It also should be noted that the conclusions one draws about the reliability of residue as a datable material may be related to the precision of the ages being examined and to the goals of the analysis. For the data set examined here, ages on residue have standard deviations ranging from 15 to $60 \mathrm{yr}$, but the modal value is $15 \mathrm{yr}$ (12 cases) and only 2 values were over $20 \mathrm{yr}$ ( 1 each of 25 and $60 \mathrm{yr}$ ). Many of the context dates on annuals from the same sites have standard deviations in the 20-35 yr range. Tests of contemporaneity, therefore, are narrowly drawn.

Obtaining age determinations with this level of precision has been deliberate, however, for the chronology-building goals for the Central Plains tradition go beyond simply determining its overall temporal parameters, and extend to evaluating the internal chronology as a prerequisite for evaluating cultural processes. With structure use-lives on the order of a decade, the Central Plains tradition presents a situation of moderately fine-grained temporal resolution. Rather than simply assigning general temporal parameters or revising previously assigned temporal parameters, the goal now is to establish a timeline against which the overall course of Central Plains tradition origins and expansion can be traced. In conjunction with similar AMS dating on earlier and later cultural traditions, it becomes possible to individually track various events such as the adoption of specific cultigens, the beginnings of village life, major subsistence shifts, or even a mundane event such as a notable change in pottery surface treatment (e.g. Roper 2011c). This requires not only high-precision dates but also comparability of ages on various short-lived materials. Therefore, the selection of material for dating does matter considerably. The uncertainties associated with old wood have been shown to produce results that are too unreliable for this purpose in this cultural setting (Roper and Adair 2011: 15). Without informed sample selection, age determinations on residue also appear to produce a timeline that is age offset from a timeline produced using age determinations on annual plant remains. Worse, a residue-based timeline appears to be composed of age determinations that exhibit varying age offsets, as do old-wood-affected charcoal dates, thus not only producing a timeline that is too old, but also distorting the temporal relations among samples and contexts, and blurring the very distinctions being sought.

In short, food residue as the archaeologist recovers it many centuries after its formation may not, after all, be only food. Until such time as its chemical properties are better understood and a means of sorting old-carbon-affected samples from those not so affected is derived, it is necessary to be cautious in using this material for age determinations. Another way to say this is: the food is contemporaneous with the occupation, but is all its carbon equally contemporaneous with the occupation? This is something we never really thought about until we began dating food residue. Other materials have been individually vetted for their reliability—it is necessary to do the same for food residue.

\section{ACKNOWLEDGMENTS}

Primary reporting of all dates analyzed herein is in other publications, cited in Table 1. Funding sources for obtaining these dates and institutional/agency permissions to date the sampled materials are acknowledged in those publications. Publication of this article was funded in part by the Kansas State University Open Access Publishing Fund. 


\section{REFERENCES}

Adair MJ. 2003. Great Plains paleoethnobotany. In: Minnis PE, editor. People and Plants in Ancient Eastern North America. Washington, DC: Smithsonian Books. p 258-346.

Ahler SA, Johnson CM, Haas H, Bonani G. 2007. Radiocarbon dating results. In: Johnson CM, Ahler SA, Johnson CM, Haas H, Bonani G, editors. A Chronology of Middle Missouri Plains Village Sites. Smithsonian Contributions to Anthropology, Number 47. Washington, DC: Smithsonian Institution Scholarly Press. p 53-89.

Beck ME. 2010. Ceramic vessel use and use alteration: insights from experimental archaeology. In: Ferguson JR, editor. Designing Experimental Research in Archaeology: Examining Technology Through Production and Use. Boulder: University Press of Colorado. p 47-69.

Blakeslee DJ. 1994. Reassessment of some radiocarbon dates from the Central Plains. Plains Anthropologist 39(148):203-10.

Boudin M, Van Strydonck M, Crombé P. 2009. Radiocarbon dating of pottery food crusts: reservoir effect or not? The case of the Swifterbant pottery from Doel "Deurganckdok" (Belgium). In: Crombé P, Van Strydonck M, Sergent J, Boudin M, Bats M, editors. Chronology and Evolution in the Mesolithic of North-West Europe. Newcastle upon Tyne: Cambridge Scholars Publishing. p 727-45.

Boudin M, Van Strydonck M, Crombé P, De Clercq W, van Dierendonck RM, Jongepier H, Ervynck A, Lentacker A. 2010. Fish reservoir effect on charred food residue ${ }^{14} \mathrm{C}$ dates: Are stable isotope analyses the solution? Radiocarbon 52(2):697-705.

Craig OE, Forster M, Andersen SH, Koch E, Crombé P, Milner NJ, Stern B, Bailey GN, Heron CP. 2007. Molecular and isotopic demonstration of the processing of aquatic products in Northern European prehistoric pottery. Archaeometry 49(1):135-52.

Crombé P, Robinson E, Van Strydonck M, Boudin M. 2012. Radiocarbon dating of Mesolithic open-air sites in the Coversand Area of the North-west European Plain: problems and prospects. Archaeometry. doi: 10.1111/j.1475-4754.2012.00693.x.

Cummings LS, Roper DC. 2010. Ancient recipes revealed!: FTIR analysis of Central Plains tradition pottery. Poster presented at the 68th Plains Anthropological Conference, Bismarck, North Dakota.

Cummings LS, Logan MK, Puseman K, Varney RA, Murphy M, Kováčik P. 2011. Organic residue (FTIR) analysis and AMS radiocarbon dating of samples from sites 25FT54, 25FT56, 25FT354, and 25RW1, Red Willow Creek Valley, Nebraska. Prepared for Kansas State University. PaleoResearch Institute Technical Report 11-140. Golden: PaleoResearch Institute.

Fischer A, Heinemeier J. 2003. Freshwater reservoir effect in ${ }^{14} \mathrm{C}$ dates of food residue on pottery. Radiocar- bon 45(3):449-66.

Hallgren F, Possnert G. 1997. Pottery design and time: the pottery from the TRB site in Skogsmossen, in view of the AMS-datings of organic remains on potsherds. Tor 29:113-36

Hart JP. 2011. The death of Owasco—redux. In: Rieth C, Hart JP, editors. Current Research in New York Archaeology: A.D. 700-1300. New York State Museum Record 2. Albany: The New York State Education Department. p 95-108.

Hart JP, Brumbach HJ. 2003. The death of Owasco. American Antiquity 68(4):737-52.

Hart JP, Brumbach HJ. 2005. Cooking residues, AMS dates, and the Middle-to-Late Woodland transition in central New York. Northeast Anthropology 69:1-33.

Hart JP, Lovis WA. 2007a. A multi-regional analysis of AMS and radiometric dates from carbonized food residues. Midcontinental Journal of Archaeology 32: 201-61.

Hart JP, Lovis WA. 2007b. The freshwater reservoir and radiocarbon dates on cooking residues: old apparent ages or a single outlier? Comments on Fischer and Heinemeier (2003). Radiocarbon 49(3):1403-10.

Hohman-Caine CA, Syms EL. 2012. The Age of Brainerd Ceramics. Report to Minnesota Arts and Cultural Heritage Fund. Hackensack: Soils Consulting.

Kriiska A, Lavento M, Peets J. 2005. New AMS dates of the Neolithic and Bronze Age ceramics in Estonia: preliminary results and interpretations. Estonian Journal of Archaeology 9(1):3-31.

Louwe Kooijmans LP. 2010. The ceramisation of the Low Countries, seen as the result of gender-specific processes of communication. In: Venmontfort B, Louwe Kooijmans L, Amkreutz L, Verjart L, editors. Pots, Farmers and Foragers. Archaeological Studies Leiden University 20. Leiden: Leiden University Press. p 27-39.

Miyata Y, Minami M, Onbe S, Sakamoto M, Matsuzaki H, Nakamura T, Imaura M. 2011. Difference in radiocarbon ages of carbonized material from the inner and outer surfaces of pottery from a wetland archaeological site. Proceedings of the Japan Academy Series B 87:518-28.

Philippsen B, Kjeldsen H, Hartz S, Paulsen H, Clausen I, Heinemeier J. 2010. The hardwater effect in AMS ${ }^{14} \mathrm{C}$ dating of food crusts on pottery. Nuclear Instruments and Methods in Physics Research 268(7-8):995-8.

Redmond BG. 2006a. A Report of Archaeological Investigations at the Danbury Site (33ot16):2005 Season. Archaeological Research Reports, No. 147. Cleveland: Cleveland Museum of Natural History.

Redmond BG. 2006b. Saving the Danbury site (33Ot16). Available at http://www.ohioarchaeology.org.

Ritterbush LW. 2002. Leary site revisited: Oneota and Central Plains tradition occupation along the lower Missouri. Plains Anthropologist 47:2514-64. 
Roper DC. 2005. Ceramic period components at the Claussen site, 14WB322, Wabaunsee County, Kansas. The Kansas Anthropologist 26:65-119.

Roper DC. 2006. The Central Plains tradition. In: Hoard RJ, Banks WE, editors. Kansas Archaeology. Lawrence: University Press of Kansas. p 105-32.

Roper DC. 2011a. Shell-tempered pottery on the Central Plains. Southeastern Archaeology 30:268-87.

Roper DC. 2011b. Examining pottery's role in Central Plains tradition foodways. Paper presented at the 69th Plains Anthropological Conference, Tucson, Arizona.

Roper DC. 2011c. The chronological position of 14RC410, a Little River focus site in Rice County, Kansas, and its implications. Plains Anthropologist 56(220):347-63.

Roper DC. 2012a. New AMS radiocarbon dating results for Central Plains tradition sites in Kansas and Nebraska. Plains Anthropologist 57(221):39-52.

Roper DC. 2012b. Refining the eastern Central Plains tradition chronology: results of a critical assessment of the radiocarbon age determinations dataset. Paper presented at the 34th Flint Hills Archaeological Conference, Emporia, Kansas.

Roper DC, Adair MJ. 2011. Interpreting AMS radiocarbon age determinations from selected Central Plains tradition sites. Plains Anthropologist 56(217):3-22.
Roper DC, Adair MJ. 2012. Additional AMS radiocarbon age determinations for the Central Plains tradition. Plains Anthropologist 57(221):31-8.

Roper DC, Reed H. 2003. The 1970 excavations at 14SA415: a Smoky Hill phase lodge. The Kansas Anthropologist 24:45-67.

Schulenberg JK. 2002. New dates for Owasco pots. In: Hart JP, Rieth CB, editors. Northeast Subsistence-Settlement Change, A.D. 700-1300. Bulletin 496. Albany: New York State Museum. p 153-65.

Shishlina NI, van der Plicht J, Hedges REM, Zazovskaya EP, Sevastyanov VS, Chichagova OA. 2007. The Catacomb cultures of the Northwest Caspian Steppe: ${ }^{14} \mathrm{C}$ chronology, reservoir effect, and paleodiet. Radiocarbon 49(2):713-26.

Swanton JR. 1942. Source Material on the History and Ethnology of the Caddo Indians. Norman: University of Oklahoma Press.

Timofeev V, Zajceva G, Possnert G. 1995. Neolithic ceramic chronology in the south-eastern Baltic area in view of ${ }^{14} \mathrm{C}$ accelerator datings. Fornvännen 90:1928.

Witty Jr TA. 1962. Archeological Investigations of the Hell Creek Valley in the Wilson Reservoir, Russell and Lincoln Counties, Kansas. Anthropological Series Number 1. Topeka: Kansas State Historical Society. 